\title{
Psychological support for professional development of people with disabilities and special needs: An overview
}

\author{
Anna Chernaya, Yulia Obukhova* \\ South Federal University, Department of Development Psychology, 344006 Rostov-on- \\ Don, Russia
}

\begin{abstract}
The paper addresses some core problems pertaining to psychological support for professional development of disabled people and individuals with special needs as well as means of their resolution in Russia and abroad. Underscored is the need for relevant prophylactic, correctional and educational programs designed to: (1) provide assessment of adequacy of occupational choice; (2) promote effective professional education, training, and career building; (3) implement monitoring of professional adaptation and development of people with disabilities and special needs as the primary target population.
\end{abstract}

\section{Relevance}

Strong trends toward inclusivity in modern society necessarily encompass social guaranties of equal opportunity professional employment for people with disabilities and special needs, i.e., opportunities suited to their professional interests and career expectations. However, in reality these very people, especially of younger ages, often encounter serious problems of underemployment or/and inadequate professional adaptation. As a result, they are susceptible to a possibility of social isolation and general maladjustment, while society, as a whole, faces challenges of limited workforce, related to it work overload of the economically active part of the population, rising social tensions - i.e., threats and dangers typical for societies with unequal opportunities. Successful professional development of people with disabilities and special needs, on contrary, enables their full participation in social life, efficient personal and professional self-realization.

Contemporary research in the area of professional development of people with disabilities and special needs - from professional choice and self-determination to actual employment and subsequent professional self-realization - are aimed to advance and enrich classical psychological and acmeological understanding of personal and professional selfconceptualization. They include, among other facets, analyses of relevant prophylactic, correctional, and educational programs for adequately supporting professional orientation, development, and self-realization, as well as reliable methods of assessment and monitoring

\footnotetext{
${ }^{*}$ Corresponding author: uvobukhova@yandex.ru
} 
of effectiveness of these and like programs. Within this framework, the role and responsibility of skilled psychological aid for people with disabilities and special needs throughout processes of their professional development, vocational and postsecondary education, employment and actual job performance are especially relevant and important.

Research on professional self-determination in personal and developmental psychology traditionally is based on a number of frameworks, namely: activity-oriented (e.g., E.A. Klimov, N.S. Pryazhnikov); focused on personality (e.g., A.B. Orlov, M.R. Ginzburg, D.A. Leont'ev); differential diagnostic-driven (e.g., F. Parsons); psychodynamic (e.g., E. Rou, U. Mozer); typological (e.g., D. Holland). New conceptual developments and directions in research have appeared recently - all adding to practice of psychological help for people with disabilities and special needs. Most prevalent tendencies in applied research have concentrated on finding effective means for overcoming challenges of 'social exclusion' and limitations in professional education, employment and career-building - i.e., the problems that continue to disadvantage this special population.

Indeed, the reality is that, despite repeatedly declared in international documents and established by law of many countries equal rights to work, people with disabilities and special needs do not enjoy the same access to employment as their non-handicapped colleagues do. According to Ali et al., the proportion of unemployed people with disabilities in USA who would like to work but cannot find job is approaching $80 \%$ [1]. Difference in employment status among disabled people often could be attributed to their levels of formal education [2, 3]. Another socio-economical factor that aggravates the problem is anticipated potential financial losses, businesses see as inevitably associated with employing people with disabilities and special needs [4, 5]. However, the overall social benefit of addressing the issue makes commercial considerations less relevant, while more humanitarian aspect of the problem takes precedence.

In addition to social contexts, practical psychologists focus attention on the important issue of personal determinants of professional development of people with disabilities and special needs. Research has extensively addressed: various aspects of their professional self-realization (S.I. Kudinov, S.S. Kudinov et al.); development of new methods and techniques for supporting their professional self-determination and development (Yu.P. Povaryonkov, L.M. Mitina et al.); assistance in overcoming difficulties in professional self-realization (L.A. Golovej, V.P. Manukyan et al.) $[6,7,8]$. D.A. Odeleye emphasizes importance of applied professional development programs for students with disabilities to provide them with the opportunities for successful professional education, early professional orientation and employment competitiveness [9]. Harley, Ysasi et al. advocate for the need to create and implement adaptive programs of psychological support for career choice, including selection of a relevant postsecondary institution [10].

In the focus of attention by Bowker \& Tuffin and Seymour \& Lupton is development of online educational programs and self-testing tools for people with disabilities $[11,12]$. Burgstahler \& Doyle describe techniques of creating Internet forums for disabled people where they could exchange professional information [13]. Burgstahler does summarise experiences of providing online guidance toward social integration for people with special needs [14]. Another facet of the research literature is analyses of professional training for specialists working with people with disabilities and special needs. K. Pierce, S. McDermott, and S. Butkus emphasize how much such an expert could contribute to development of adaptive resources at various stages of a person's professional selfrealization [15]. So, it is imperative to carefully study activity of consultants specialized in professional orientation of people with disabilities and special needs, their ability to adopt standards and insights of contemporary inclusive education, to develop competencies essential for effective psychological support for clients with special needs. Among these 
skills and competencies is the ability to work in multidisciplinary teams of professionals, to navigate relevant norms and regulations to efficiently implement techniques of psychological and other kinds of support for specific categories of people in course of their professional development [16, 17, 18]. Of special interest here are, accomplished by practical psychologists, adaptation of classical and construction of new specialized psychodiagnostic instruments for studying professional development of people with disabilities and special needs that would take into account their typological and unique psychological characteristics. For example, Russian laboratory «Гуманитарные технологии» (https:/htlab.ru) has accumulated substantial experience in methodological support for unemployment services in activities of professional orientation, development of tests for complex psychological diagnostics, design and implementation of applied scientific research including studies focused on problems emblematic for people with disabilities and special needs.

\section{Major problems and possible solutions}

Further in the review we consider the most important problems of professional development in the context of analyzing resource abilities of practical psychological support for people with disabilities and special needs.

The first cluster of problems is composed of a problem of social and psychological status of disabled people engaged in any kind of work and a problem of employers' attitudes. The majority of employers is not predisposed to hiring disabled people or people with limited health capacities for different reasons, acknowledging their high empathy, but doubting their competence. From the other side, employees can be shy of their own disability and fear unfair treatment if their disability is exposed. Moreover, disabled people can appraise different individual job characteristics, e.g., promised working hours or benefits provided, as insufficient in comparison with regulations regarding their state disability benefits [19]. Concern over the biased expectations of people with disabilities has been often raised in the literature [e.g., 20]. This can lead disabled job applicants to concealing their disability status. Only 10 to $16 \%$ of able-bodied Americans report disability [3, 21]. In Canada, this indicator is about $11 \%$ [22], $16 \%$ in the UK [23] and $15 \%$ in the Netherlands and Sweden [24, 25]. In Russia, no similar monitoring has been conducted yet. Santuzzi et al. claim that the majority of people with episodic health problems (diabetes, arthritis, depression) do work in organizations, but since applicants prefer to hide this fact, such cases are not reflected in official statistics [26]. Most often, such applicants deceive the employer in order to get the job and do not feel any different from their peers $[26,27]$. There is evidence that some leaders discriminate against people with disabilities [5] or make various employment decisions based on their disability status [28]. People with disabilities are often advised not to disclose information in the early stages of employment (for example, during an interview) and either to do it only after receiving a job offer or not to disclose the fact at all until it becomes a necessity [29]. In such cases, however, a person with disabilities will be frustrated; the level of anxiety and self-doubt will increase, which may in turn affect psychological health.

Nowadays, there is enough experience in developing and implementing different programmers and courses for both disabled people and employers; this has been gained while providing psychological services, running assessment centers, working as professional psychologists and consultants. All these focus on expanding knowledge about disability, its legislative and legal, status, about socio-psychological characteristics of employing disabled workers in various professions, on increasing competence in handling 
people with disabilities and / or their families in the framework of organizing professional activities [30]. For example, the Job Accommodation Network (JAN), a free advisory service provided by the Office of Disability Employment Policy of the US Department of Labor, is successfully operating in the United States. Its task is to counsel employers on issues of socialising employees with disabilities (https://askjan.org).

The second important set of problems includes assessing personal and professional potential of people with disabilities for hiring. One of the most common prejudices that affect people with disabilities and special needs is that they are perceived by employers as not willing to work at all [31]. Many employers hold poorly grounded stereotypical views on the potentials of people with disabilities that often permeate the entire work cycle. S. Bonaccio, C.E. Connelly, I.R. Gellatly et al. do not only describe in detail the problems that employers face when hiring disabled people (from employment to its termination), but also provide guidelines for resolving them [32]. The process of selecting and evaluating candidates with disabilities is characterized by the fact that recruitment managers do not always adequately respond to applicants with disabilities, since they lack proper psychological training in working with such people. Only a number of foreign organizations provide training for employers and heads of human resources departments; their personnel services and approaches to interviewing candidates with disabilities could be limited or less effective, as well [33]. To solve the problem, it is necessary to offer highquality special professional training and psychological support for interviewers, which would individualize the procedure of selecting suitable employees and account for the specifics of perception of people with various diseases. Moreover, for accommodating people with disabilities and special needs it is necessary to be armed with knowledge of special psychological techniques, as well as to develop methodological tools adapted for the selection and evaluation of job candidates with disabilities and to use special computer technology in the selection process.

How to integrate disabled people in a work process is the third set of problems, which is also critically important. In particular, successful adaptation is determined by two factors. The first one is the culture of an organization, which hires disabled people. The second factor is determined by the diversity of the work and to what extent inclusive practices of labor are valued and used by managers and colleagues [34, 35]. However, compared to healthy workers, those with disabilities report more cases of hidden discrimination, such as expulsion from informal meetings or ignoring them therein [36]. Considering that subtle discrimination is just as harmful as its open forms, it seems crucial to prevent any discrimination against employees with disabilities and special needs [37]. In addition, discrimination in the past can lead to subsequent discrimination, which makes workers desguise disability symptoms and use various forms of compensatory behavior more often [38]. When such situations appear, it is not enough just to use the practices described above. In addition we have to individually work with people who show subtle discrimination for identifying its causes and putting an end to this behavior.

The fourth class of problems is also related to interactions between employees with disabilities and their colleagues. Kaye et al. note that healthy workers are concerned that employees with disabilities can interfere with the functioning of the team [5]. In particular, there may be fears that people with disabilities will have less responsibilities for the same payment, as well as access to better equipment, and a more convenient schedule. Managers may fear that colleagues will be indignant at the need to work harder to compensate for low productivity of a person with disabilities or that they will negatively relate to work perceived as being illegally redistributed [39]. As noted above, the nature of many disability restrictions is that it could be latent (colleagues may not be aware of someone else's disability). In addition, in countries with laws regarding confidentiality, managers 
cannot disclose agreements reached with employees or discuss employee's incapacity, although some factors (for example, schedule flexibility) may be obvious [26]. The resources for psychological support should provide the possibility of conducting social and psychological trainings in team building to improve the microclimate in small work groups; to study premises or conflicts to increase effectiveness and productivity of small groups and subgroups; to develop general tolerance towards people with disabilities and special needs. Additionally, psychologists can conduct explanatory conversations with employees who show hostility to their handicapped colleagues. The consultant psychologists warn managers not to provide disabled employees with unjustified benefits (because it can exacerbate manifestations of intolerance); not to open information about the employee's disability unless the manifestations of the disease are not obvious to others. All of these helps to increase the level of trust among team members and toward the leadership [40].

Thus, in order to provide professional psychologists with suitable tools and resources that can help them to achieve successful socialization, as well as to reduce the risks of stigmatization and social exclusion of people with disabilities and special needs it is important to determine the content of psychological support strategies. It can be determined through the approaches described above, because they perfectly represent the major difficulties faced by people with disabilities and special needs.

\section{References}

1. M. Ali, L. Schur, \& P. Blanck, P. J. Occup Rehabil., 21(2), 199-210 (2011)

2. R. Arim Statistics Canada Cat. No. 89-654-X (Statistics Canada, Ottawa, 2015)

3. E.A. Lauer, \& A.J. Houtenville, Annual disability statistics compendium: 2016 (University of New Hampshire, Institute on Disability, Durham, 2017)

4. B. Hernandez, K. McDonald, M. Divilbiss, E. Horin, J. Velcoff, \& O. Donoso, Employ Respons Rights J., 20(3), 157-164 (2008)

5. H. S. Kaye, L. H. Jans, \& E.C. Jones, J. Occup Rehabil., 21(4), 526-536 (2011)

6. S.I. Kudinov, S.S. Kudinov, Sib. ped. zhurnal, 5, 272-280 (2010)

7. L.M. Mitina, L.I. Akovanceva et al, Issledovanie psihologicheskih osobennostej sub"ektov inklyuzivnogo obrazovaniya s uchetom mezhdunarodnogo opyta (NestorIstoriya, Sankt-Peterburg, 2015)

8. L.A. Golovej, V.R. Manukyan, L.V. Rykman i dr. Professional'noe razvitie lichnosti: nachalo puti (empiricheskoe issledovanie). (Nestor-Istoriya, Sankt-Peterburg, 2015)

9. D.A. Odeleye Education Community, 23-37 (2010)

10. D.A. Harley, N.A. Ysasi and el. Disability and Vocational Rehabilitation in Rural Settings (Springer, New York, 2017)

11. N. Bowker \& K. Tuffin, Disability \& Society, 17(3), 327-344 (2002)

12. W. Seymour \& D. Lupton, Disability and Society, 19(4), 291-305 (2004)

13. S. Burgstahler \& A. Doyle, Disability Studies Quarterly, 25(2) (2005)

14. S. Burgstahler, Currents in Teaching \& Learning, 3(6) (2017)

15. K. Pierce, S. McDermott, S. Butkus, Research in Developmental Disabilities, 24(5), 369-380 (2003)

16. J.E. Ormrod, Educational psychology: Developing learners (Prentice Hall, New Jersey, 2003)

17. J. Wadsworth, A. Milson \& K. Cocco, Professional School Counseling, 8, 141-147, (2004)

18. S.M. Reis, R.D. Colbert \& T.P. Hébert, Roeper Review, 27, 110-120 (2005)

19. E. Fabian Work and disability (Oxford University Press, New York, 2013)

20. A. Colella, A.S. DeNisi \& A. Varma, J. Appl. Phys, 83(1), 102-111 (1998) 
21. L. Kraus 2016 disability statistics annual report (University of New Hampshire, Durham, 2017)

22. M. Turcotte Persons with disabilities and employment (Statistics Canada Cat. No. 75 006-X). (Statistics Canada, Ottawa, 2014)

23. Department for Work \& Pensions, Office of Disability Issues Official statistics: Disability facts and figures (2014)

24. Statistics Netherlands Nearly 1.7 million disabled people in the Dutch labour force (2010)

25. Statistics Sweden The labour market situation for people with disabilities 2016 (Information om utbildining och arbetsmarknad rapport 2017:2). Stockholm: Statistics Sweden (2017)

26. A. M. Santuzzi, P.R. Waltz, L.M. Finkelstein\& D.E. Rupp, Indust. and Organiz. Psychol., 7(2), 204-219 (2014)

27. A. Jetha, J. Bowring, S. Tucker, C.E. Connelly, K.A. Martin Ginis, L. Proulx, M.A.M. Gignac, Disability and Rehabil., 40:26, 3127-3135 (2018)

28. S.F. Premeaux, J. of Business and Psychology, 16(2), 291-298 (2001)

29. S. Von Schrader, V. Malzer \& S. Bruyère, Employee Responsibilities and Rights J., 26(4), 237-255 (2014)

30. A.V. Chernaya, J. of Social Studies Education Research, 9(4), 140-167 (2018)

31. E. Hemphill \& C.T. Kulik, Social Policy and Society, 15(4), 537-554 (2016)

32.S. Bonaccio, C.E. Connelly, I.R. Gellatly et al., J. Bus. Psychol., 1-24 (2019) doi:10.1007/s10869-018-9602-5

33. W.A. Erickson, S. von Schrader, S.M. Bruyère \& S.A. VanLooy. Rehabil. Counseling Bulletin, 57(4), 195-208 (2014)

34. L. Schur, D. Kruse, J. Blasi \& P. Blanck, Industrial Relations: A Journal of Economy and Society, 48(3), 381-410 (2009)

35. K. Vornholt, S. Uitdewilligen \& F.J. Nijhuis, J. Occup Rehabil., 23(4), 463-475 (2013)

36. M.D. Naraine \& P.H. Lindsay, Disability \& Society, 26(4), 389-403 (2011)

37. K.P. Jones, C.I. Peddie, V.L. Gilrane, E.B. King \& A.L. Gray, J. of Management, 42(6), 1588-1613 (2016)

38. A.K. McGonagle \& L.E. Hamblin, J. Bus Psychol., 29(3), 427-442 (2014)

39. A. Kosny, M. Lifshen, D. Pugliese, G. Majesky, D. Kramer, I. Steenstra, S. Soklaridis, \& C. Carrasco, J. Occup Rehabil., 23(3), 438-449 (2013)

40. A.V. Sidorenkov, O.Yu. Shipitko, N.Yu. Ulyanova, Y.V. Obukhova, The Social Sciences (Pakistan), 11, 6999-7010 (2016) 